\title{
The influence of loyalty programs on South African Youth's repeat purchase behaviour
}

\author{
Siphiwe Dlamini \\ University of Cape Town, South Africa \\ Nathalie Beatrice Chinje \\ China Europe International Business School (CEIBS-Africa)
}

\section{Keywords}

Customer Commitment, Customer Satisfaction, Customer Trust, Loyalty programs, Repeat Purchase Behaviour

\begin{abstract}
Despite the substantial interest in loyalty programs amongst marketing scholars and professionals, few studies have been conducted amongst the youth within emerging markets. The purpose of the study was to examine the mediating influence of customer satisfaction, trust, and commitment on the relationship between loyalty programs and repeat purchase behaviour of a group of South African youth. The methodology involved a self-administrated questionnaire adapted from previous similar studies. Data were collected from 263 South African young people between the ages of 18 and 24 who were retail loyalty program members. The study tested six hypotheses using Structural Equation Modeling. The software used was SPSS 22 for descriptive statistics and IBM Amos 22. The findings indicate that all hypotheses were supported. They also suggest the significance of customer satisfaction as a strong mediator of loyalty programs and repeat purchase behaviour. Moreover, the study reveals that the mediating influence of customer commitment on loyalty programs and repeat purchase behaviour was the weakest influence. The findings revealed that, by building customer satisfaction and customer trust amongst the youth, the potential for marketers to positively impact on the success of loyalty programs and repeat purchase behaviour is high. This paper makes a valuable contribution to the literature on loyalty programs amongst youth within a developing market context.
\end{abstract}

Corresponding author: Siphiwe Dlamini

Email address for corresponding author: Siphiwe.dlamini@uct.ac.za

First submission received: $2^{\text {nd }}$ October 2018

Revised submission received: $18^{\text {th }}$ January 2019

Accepted: 25th January 2018

\section{The introduction}

Loyalty programs have been found to be commonly used in retail as a customer relationship management tool to acquire and retain customers (Goel, Kamble, Banerjee and Goel, 2017; Kang, Alejandro and Groza, 2015). This body of research explains their wide adoption amongst companies across different markets (Leva and Ziliani, 2017; Söderlund and Colliander, 2015). Loyalty programs are immensely popular globally, with $90 \%$ of European and United States customers being members of at least one loyalty program (Meyer-Waarden, 2015). In the U.S alone, there are 2.1 billion loyalty program memberships growing at 16\% annually (Meyer-Waarden, 2015). In South Africa, the number of loyalty program memberships has increased from 12 to 15 million registered members in 2007 (Oliver, 2007), with Pick ' $n$ Pay having 8.9 million members and the Edcon group having 12 million members by 2015, while Clicks and Woolworths have 5 and 3.1 million members, respectively. There are over 70 loyalty programs in South Africa, and many are found in the retail sector. The most significant value of a loyalty program has been found to be that of increasing sales and retaining valued customers (Bolton, Kannan and Bramlett, 2000; Lee, Tsang and Pan, 2015; Lima and Lee, 2015). Gomez, Arranz and Cillán (2006) suggest that companies use loyalty programs as a specific marketing strategy to secure customer loyalty.

Most prior studies have investigated the effect of one or two of the three predictors of customer loyalty (Stathopoulou and Balabanis, 2016; Pandit and Vilches-Montero, 2016; Baloglu, Zhong and Tanford, 2017); but none has examined the joint effects of all three on loyalty programs and repeat 
purchase behaviour. Our study intends to fill this gap by investigating the combined effect of customer satisfaction, trust, and commitment on loyalty programs and repeat purchase behaviour. We consider thorough knowledge about such mediating effects to be vital to the marketing strategy of products and services, since all these effects need to be considered when planning and evaluating actions to be taken to increase customer share of wallet (Magi, 2003). Notwithstanding studies showing the positive effect of loyalty program benefits on customer satisfaction (Stathopoulou and Balabanis, 2016), many retailers do not have loyalty programs in place geared towards a specific market, in this instance, the youth aged between 18 and 24. Considering that the youth represent a significant future earning potential, one would expect that retailers would target them from an early age in order to generate a long-term relationship with them, and thereby achieve customer lifetime value.

Loyalty programs, benefits, and customer trust in a service provider have been clearly shown to influence consumer behaviour (Baloglu et al., 2017) and much of the literature suggests that satisfaction and trust are key determinants of loyalty (Pandit and Vilches-Montero, 2016). Thus, given these insights on loyalty programs, the research question that this paper seeks to answer is, what is the degree to which, and what is the nature of, the influence of loyalty programs on the repeat purchase behaviour of South African youth? In answering this question, the study makes a potentially valuable contribution to the loyalty program, youth and emerging market literature by providing empirical evidence to fill several research gaps.

We found the first gap in the extant literature to be the narrow focus on financial benefits and their effects on loyalty programs (Henderson, Beck and Palmatier, 2011), and on the effects of customer satisfaction, while customer trust and customer commitment remain largely unexplored. Secondly, loyalty program members belong to different segments of the consumer population and should thus be given different benefit offers (Söderlund and Colliander, 2015). However, no studies have to date investigated the specific effects of loyalty programs on the youth, a crucial segment of the consumer population for many retailers. Lastly, while loyalty programs have reached saturation in most developed markets and are growing rapidly in emerging markets (Yan \& Cui, 2016), there exists limited empirical findings of loyalty programs and repeat purchase behaviour in emerging markets. In addition, several existing studies have revealed that customers in emerging markets may present diverse purchasing behaviours from those of customers in developed markets (Atsmon, Kuentz and Seong, 2012).

The next section discusses the key constructs of the study and related hypotheses. The methodology section follows and a discussion of results, implications, limitations of the study and future research conclude the paper.

\section{Literature review}

\subsection{Loyalty programs}

Yi and Jeon (2003) define a loyalty program as a marketing program that drives customer loyalty and rewards profitable customers. Evanschitzky, Iyer, Plassmann, Niessing and Meffert (2012) see loyalty programs as a marketing to increase sales and retain customers. The value of a loyalty program is dependent upon the customer appreciation, or positive perception, of its benefits or rewards (Lee et al., 2015). Successful loyalty programs can be implemented if clear company goals are established, along with suitable systems for implementation and measurement (Lee et al., 2015). Dowling and Uncles (1997) saw loyalty programs as being beneficial for the following reasons: serving loyal customers is cost effective, such programs are less price sensitive, more profitable, and loyal to customers, and become advocates for the company. More importantly, according to Beneke, Blampied, Cumming and Parkfelt (2015), the main objective of customer loyalty programs is to cultivate customer retention, increase satisfaction and drive value for customers. Loyalty programs can offer customers benefits in exchange for repeat purchase to a company (Noble, Esmark and Noble, 2014). Undoubtedly, as many studies have shown, loyalty programs have become a strategic marketing tool to encourage behavioural customer loyalty (Evanschitzky et al., 2012; Agudo, Crespo and del Bosque 2012; Leenheer, Van Heerde, Bijmolt and Smidts, 2007). Omar and Musa (2009) assert that loyalty programs are a systematic process of recruiting, selecting, maintaining, and capitalising on customers. The intended purpose of loyalty programs is for companies to reward loyal customers and influence their purchase behaviour (Dorotic, Bijmolt and Verhoef, 2012; Omar and Musa, 2009). 


\subsection{Customer satisfaction}

Creating and maintaining customer satisfaction is one of the greatest modern challenges, faced by management, as well as being an urgent priority (Veloutsou, 2015; Radojevic, Stanisic and Stanic, 2015). Keropyan and Gil-Lafuente (2012) also see customer satisfaction as a major objective of marketing and the vital importance for companies to keep their customers satisfied. When the customer is at the heart of a company, the company grows more satisfied customers (Aktepe, Ersöz and Toklu, 2015). Customer satisfaction, switching cost, and trust in a company all have an impact on customer loyalty (Minarti and Segoro, 2014). Customer satisfaction, customer loyalty, internal marketing, and consumer behaviour are all interconnected and should be vital for customer retention (Roberts-Lombard, 2009). While researchers such as Barkaoui, Berger and Boukhtouta (2015) see customer satisfaction levels as relating directly to a company's service quality, two decades ago Bowen and Shoemaker (1998) argued that satisfied customers are not automatically loyal. Instead, according to Omar, Wel, Aniza, Musa and Nazri (2010), customer satisfaction is defined as a measure of the degree to which a customer's expectations are met. Customer satisfaction in this paper is defined broadly in terms of a company exceeding all customer expectations and fulfilling all the needs of its customers (Terblanche and Boshoff, 2010). According to this definition, or to these criteria, increasing customer satisfaction in any company starts with a systematic evaluation of the service quality, and in turn evaluating customer satisfaction levels according to selected criteria used to assess future performance (Aydin, Celik and Gumus, 2015). In this process, the evaluation of the service features must match the relative meaning or perceptions customers attach to the company (Mouwen, 2015). Companies implement loyalty programs in order to increase their customers' satisfaction and prevent their customers from defecting to competitors (Zakaria et al., 2014). In this context, Demoulin and Zidda (2008) found company loyalty and brand loyalty to be driven by customers who are satisfied with the company's loyalty program and are therefore less likely to be influenced by the competitors' loyalty programs. As such, loyalty programs can improve customer satisfaction (Gomez et al., 2006). Based on the research on customer satisfaction and loyalty discussed in this section, it is hypothesised that:

\section{H1. Loyalty programs have a positive influence on customer satisfaction}

\subsection{Customer trust}

There are various definitions of trust as applied to customers' relationship to a service or product. Chinomona, Mahlangu and Pooe (2013) define trust in this context as the customer's belief that she or he can rely on a service or product. A relationship built on trust enables customers to believe in, and be devoted to, that relationship (Morgan \& Hunt, 1994), and in this way creates customer loyalty (Caceres and Paparoidamis, 2007). Trust is a key enabler when developing sustainable relationships with customers (Omar et al., 2010; Garbarino and Johnson, 1999). Trust is developed over time and is dependent on the quality of the customers' experience with the company (Xie, Peng and Huan, 2014). Trust itself is reliant on three variables: shared values, communication, and opportunistic behaviour (Keh and Xie, 2009). Chen and Quester (2015) define trust from a cognitive and affective perspective. Cognitive trust comes from the consumer's thoughts and her/his critical evaluation of a company, service or product, and is thus knowledge-driven, reflecting the consumer's confidence in, or eagerness to rely on, the capability and consistency of a company or product (Chen and Quester, 2015). Agudo et al. (2012) define trust in terms of the creation and maintenance of profitable relationships between the customer and the company. In this paper, customer trust is seen as a customer confidently believing in the honesty and sincerity of the company (Morgan \& Hunt, 1994).

Thus, according to this definition and criterion, a loyalty program enables a relationship between the customer and company to be built in such a way as to reinforce the concept of trust and commitment (Gomez et al., 2006). A loyalty program favours the customer's trust and commitment to the company (Gomez et al., 2006). Trust thus represents the level of confidence that the loyalty program members have in both the loyalty program and the company, and that the company's belief that the likely behaviour of the customer will translate into a valued outcome for the company (Omar et al., 2009). Therefore, according to this definition of trust, it is hypothesised that:

\section{H2. Loyalty programs have a positive influence on customer trust}




\subsection{Customer commitment}

Customer commitment is a key intermediary in a thriving company, together with customer relationship and customer retention (Garbarino and Johnson, 1999; Amine, 1998). Marketing scholars have acknowledged an interrelationship between commitment and customer retention (Fullerton, 2004). Once committed, the customer stays loyal to the company to avoid switching costs, and is emotionally connected to the company (Kao, 2015). The level of commitment is based on the relationship investments, relationship benefits, and possible termination costs (Chang and Chen, 2011). According to Fullerton (2004), and Sanchez and Iniesta (2004), developing a social connection between the company and its customers is vital for commitment. Additionally, commitment is largely based on the customer's perception and beliefs about the company (Sanchez and Iniesta, 2004). Mattila (2006) acknowledges that commitment has an influence on a loyalty program through the shared emotional connections between the customer and the company. A shift takes place from customer commitment towards customer intimacy, and the key to sustaining a high level of commitment is to create a high level of passion and intimacy (Bugel, Verhoef and Buunk, 2010).

Empirical research has found loyalty programs to support customer recognition of switching costs, therefore building customer commitment and retention (Lee et al., 2015). Lim and Lee (2015) note a loyalty program as the pre-commitment to a low future price by the company. It is the role of commitment that underlines the effectiveness of loyalty programs (Garnefeld, Eggert, Helm and Tax, 2012). Loyalty programs help build customer commitment and this shows that - or the perception is that - the company is committed to the customer's needs (Liu, 2007; Yi and La, 2004). While it is unlikely that a customer is fully committed to a single brand or company, nevertheless loyalty programs have the potential to improve customer commitment and to minimise customer defection (Liu, 2007). In a nutshell, loyalty program rewards produce commitment (Lee et al., 2015). Furthermore, Liu (2007) believes that customers are more likely to be committed to a loyalty program that they trust. Thus, the hypothesis is:

\section{H3. Loyalty programs have a positive influence on customer commitment}

\subsection{Repeat purchase behaviour}

Repeat purchase is the main source of revenue for companies (Hsu, Chang and Chuang, 2014). Researchers and marketers have labelled customers who repeat purchases as loyal customers (LiuThompkins and Tam, 2013), recognising that a past purchase behaviour often leads to, and is an indication of, continued behaviour (Martin, Mortimer and Andrews, 2015). According to Eason, Bing and Smothers (2015) the revenue generated by loyal customers will continue to grow the longer the customer remains loyal to the company; thus, loyal customers will not only pay a premium price for products, they will continue to purchase more over time if the loyalty is maintained. Paul, Hennig-Thurau, Gremler, Gwinner and Wiertz (2009) propose the characteristics of customer repeat purchase behaviour as consisting mainly of availability, service product, service environment, service delivery, expertise and reliability. In addition, loyalty program members have been found to make a greater number of visits to the retailer and to purchase far more than customers without membership (Gomez, 2006). Meyer-Waarden and Benavent (2009) suggest that loyalty programs reinforce repeat purchase behaviour rather than influence attitudes and commitment. Repeat purchase behaviour in this paper is seen as customers repeatedly purchasing goods and services from a retailer (Paul et al., 2009).

Satisfaction and profit chain model suggest that profits come from customer retention that occurs from high levels of customer satisfaction, which is achieved by delivering a quality product or service (Mathe-Souleka, Slevitch and Dallinger, 2015). Satisfied customers are likely to engage in repeat purchase (Choiu and Droge, 2006; Martínez and del Bosque, 2013). However, Mägi (2003) argues that satisfied customers do not necessarily demonstrate high levels of repeat purchase behaviour, even though in most cases this is the outcome desired by the company. Instead, Leong, Hew, Lee and Ooi (2015) would argue, it is service quality that motivates repeat purchase behaviour and secures customer loyalty. Yi and La (2004) dispute the idea that customers with inferior satisfaction thresholds have a superior level of repeat purchase behaviour, while Gomez et al. (2006) are of the opinion that high expectations drive the increase in repeat purchase. Satisfied customers will tend to concentrate a large share of their expenditure on that company (Mägi, 2003). It can be noted that there is an interrelationship between customer satisfaction and 
repeat purchase behaviour (Yi and La, 2004; Mägi, 2003). Given this argument, the fourth hypothesis is stated as:

\section{H4. Customer satisfaction has a positive influence on repeat purchase behaviour}

Choiu and Droge (2006) suggest that a customer's post purchase satisfaction with high involvement products is influenced by trust. Financial rewards also reinforce trust and commitment and are for the most part successful in establishing a primary relationship with customers, a point of view endorsed by Lee et al. (2015). The prediction of repeat purchase intention put forward is underpinned by the idea that there is an exchange between trust and repeat purchase (Chiu, Hsu, Lai and Chang, 2012). Some studies reject the significance of trust on repeat purchase behaviour, although this view is not in line with the mainstream view that there is in fact a relationship between the two (Chiu et al., 2012). Given this argument, the authors of the current study submit that there is significant relationship between customer trust and repeat purchase behaviour. Based on this, the fifth hypothesis is stated as follows:

\section{H5. Customer trust has a positive influence on repeat purchase behaviour}

Commitment is critical to purchase behaviour (Caceres and Paparoidamis, 2007). Customers who consistently repeat purchases demonstrate that they are committed to the company (Gomez et al., 2006). Some researchers have found customers to have a deeply held commitment to purchase from the same brand in the future (Liu-Thompkins and Tam, 2013; Caceres and Paparoidamis, 2007). Some researchers see repeat purchase as a sign of typical key factors of attitude, and that commitment and repeat purchase decisions are therefore influenced by the customer's attitude (Rasheed and Abadi, 2014). Empirical findings support the positive relationship between commitment, repeat purchase, and behavioural loyalty (Omar et al., 2010). Based on this body of research, the proposed hypothesis is:

H6. Customer commitment has a positive influence on repeat purchase behaviour

Based on the previous arguments, this paper examines the mediating influence of customer satisfaction, customer trust and customer commitment in the relationship between loyalty programs and repeat purchase behaviour. Figure illustrates this process.

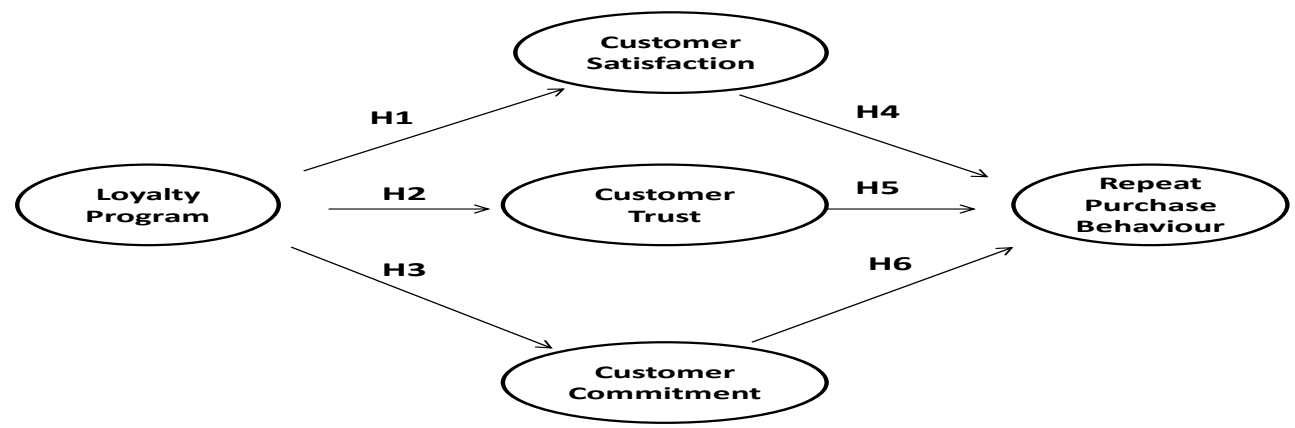

Figure 1: Conceptual model: influences on repeat purchase behaviour

\section{Research methodology}

The study used a quantitative and positivist approach. The research instrument was adapted from existing scales from prior research in a similar study. A pretest was conducted by randomly selecting ten students to test the measurement items. The data was analysed using SPSS.

\subsection{Sample and data collection}

The questionnaire was self-administrated using a sample of students aged between 18 and 24 years from the University of Witwatersrand in Johannesburg, South Africa. The research participants were screened to establish whether they were all retail loyalty program members. All questionnaires were valid 
and indicated a $100 \%$ response rate on the 263 distributed and collected. This high response rate was due to the active role of researchers in recruiting research participants. We ensured visibility and thorough completion of the questionnaire in the field by the respondents to minimise the number of invalid questionnaires. We considered the youth to be a suitable sample for this study as Statistics South Africa (2014) shows that South Africa has a young population made up of $40 \%$ of those people between the ages of 15 and 35 with a large earning potential and contributing significantly to the retail economy.

\subsection{Research instrument measurement items}

We used seven measurement items adapted from a study by Evanschitzky et al. (2012) to assess the loyalty program. Four measurement items were adapted from a study by Bridson, Evans and Hickman (2008) to assess the levels of customer satisfaction and customer commitment, respectively. In addition, we used four measurement items adapted from a study by Agudo et al. (2010) to assess the levels of customer trust of the participants. Lastly, three measurement items were adapted from a study by Gomez et al. (2006) to assess the levels of repeat purchase behaviour. The measurement items were measured using a 7-point Likert scale; one being strongly disagree, five neutral and seven strongly agree

\section{Results}

\subsection{Demographics of respondents}

Of the total number of participants, $77.6 \%$ were female and $22.4 \%$ were male. More than $50 \%$ of the respondents were between 18 and 20 years of age, and $39 \%$ of the respondents were in their third year of study. A quarter of the respondents reported being members of at least two retail loyalty programs.

\subsection{Tests of reliability and validity}

Confirmatory factory analysis was conducted using IBM Analysis of Moment Structure (AMOS) 22 to test the model fit of the measurement items. The results demonstrated a model fit. A combination of fit indices was applied to assess the model fit. Chi-square value $-\chi^{2} / \mathrm{df}=2.9612$; random measure of standard error of approximation $($ RMSEA $)=.080$; goodness-of-fit index $(\mathrm{GFI})=0.90$; incremental fit index $(\mathrm{IFI})=$ .97; Tucker Lewis index (TLI) <0.90; Normed-fit index $(\mathrm{NFI})=.96$; and comparative fit index $(\mathrm{CFI})=.97$. As exhibited in Table 1, all the Cronbach alpha values surpass the recommended threshold of 0.6, as suggested by Barakat, Ramsey, Lorenz and Gosling (2015). Cronbach's coefficient a is one of the most common internal consistency approaches (Dunn, Baguley and Brunsden, 2013). The scores were higher than the recommended threshold, with scores ranging from 0.76 to 0.88 .

The measure of composite reliability was performed. Yang, Wang and Su (2006) posit that, in reliability analysis, an acceptable Composite Reliability value must exceed 0.7. As for Composite reliability, Table 1 indicates that the values all exceed the recommended 0.7. Composite reliability values for all variables range from 0.866 and 0.920 . The Composite Reliability test is calculated using the following formula: (CR): $\mathrm{CR \eta}=(\Sigma \lambda$ yi $) 2 /[(\Sigma \lambda$ yi $) 2+(\Sigma \varepsilon i)]$.

Discriminant validity was performed to test the validity of the constructs. A good representation of the latent construct by the item is identified when the variance extracted estimate is above 0.5 (Fraering \& Minor, 2006). The results of the AVE range from 0.730 to 0.833 as seen in Table 1 . Discriminant validity was measured using inter-construct correlation matrix as seen in Table 2, which was anticipated to have loading values that are less than 0.85 . The results of the inter-construct correlation matrix range from 0.249 to 0.588 .

\begin{tabular}{|c|c|c|c|c|c|c|c|c|}
\hline \multirow{2}{*}{\multicolumn{2}{|c|}{ Research constructs }} & \multicolumn{2}{|c|}{ Descriptive statistics* } & \multicolumn{2}{|c|}{ Cronbach's test } & \multirow{2}{*}{ C.R. } & \multirow{2}{*}{ AVE } & \multirow{2}{*}{$\begin{array}{l}\text { Measurement } \\
\text { Item Loadings }\end{array}$} \\
\hline & & Mean & SD & Item-total & a Value & & & \\
\hline \multirow{7}{*}{$\begin{array}{l}\text { Loyalty Program } \\
\text { (LP) }\end{array}$} & LP1 & \multirow{7}{*}{4.11} & \multirow{7}{*}{0.721} & 0.721 & \multirow{7}{*}{0.812} & \multirow{7}{*}{0.861} & \multirow{7}{*}{0.500} & 0.681 \\
\hline & LP2 & & & 0.739 & & & & 0.795 \\
\hline & LP3 & & & 0.892 & & & & 0.812 \\
\hline & LP4 & & & 0.727 & & & & 0.568 \\
\hline & LP5 & & & 0.894 & & & & 0.596 \\
\hline & LP6 & & & 0.798 & & & & 0.674 \\
\hline & LP7 & & & 0.922 & & & & 0.655 \\
\hline \multirow{2}{*}{$\begin{array}{l}\text { Customer } \\
\text { Satisfaction (CS) }\end{array}$} & CS1 & \multirow{2}{*}{4.60} & \multirow{2}{*}{0.676} & 0.799 & \multirow{2}{*}{0.865} & \multirow{2}{*}{0.908} & \multirow{2}{*}{0.712} & 0.811 \\
\hline & CS2 & & & 0.731 & & & & 0.847 \\
\hline
\end{tabular}




\begin{tabular}{|c|c|c|c|c|c|c|c|c|}
\hline & CS3 & & & 0.866 & & & & 0.887 \\
\hline & \begin{tabular}{|l|} 
CS4 \\
\end{tabular} & & & \begin{tabular}{|l|}
0.749 \\
\end{tabular} & & & & 0.827 \\
\hline & CT1 & & & 0.837 & & & & 0.842 \\
\hline Customer Trust & CT2 & 132 & م 781 & 0.706 & o 814 & 0877 & 0642 & 0.823 \\
\hline (CT) & CT3 & 4.02 & $0 . / 01$ & 0.738 & 0.014 & $0.0 / 7$ & J & 0.830 \\
\hline & CT4 & & & 0.755 & & & & 0.693 \\
\hline & CC1 & & & 0.824 & & & & 0.852 \\
\hline Commitment & CC2 & 154 & I 677 & 0.725 & 088 & 090 & 0743 & 0.874 \\
\hline (CC) & CC3 & & & 0.929 & & & & 0.852 \\
\hline & CC4 & & & 0.877 & & & & 0.869 \\
\hline & RP1 & & & 0.912 & & & & 0.727 \\
\hline Rehaviour & RP2 & 4.27 & 0.711 & 0.738 & 0.768 & 0.866 & 0.685 & 0.885 \\
\hline & RP3 & & & 0.897 & & & & 0.862 \\
\hline
\end{tabular}

Table 1: Measurement accuracy assessment and descriptive statistics

\begin{tabular}{|l|l|l|l|l|l|}
\hline & CC & CS & CT & LP & RPB \\
\hline CC & 1.000 & & & & \\
\hline CS & 0.520 & 1.000 & & & \\
\hline CT & 0.393 & 0.569 & 1.000 & & \\
\hline LP & 0.374 & 0.588 & 0.485 & 1.000 & \\
\hline RPB & 0.423 & 0.380 & 0.249 & 0.401 & 1.000 \\
\hline
\end{tabular}

Table 2: Inter-Construct Correlation Matrix

\subsection{Path model}

Figure 2 illustrates this process.

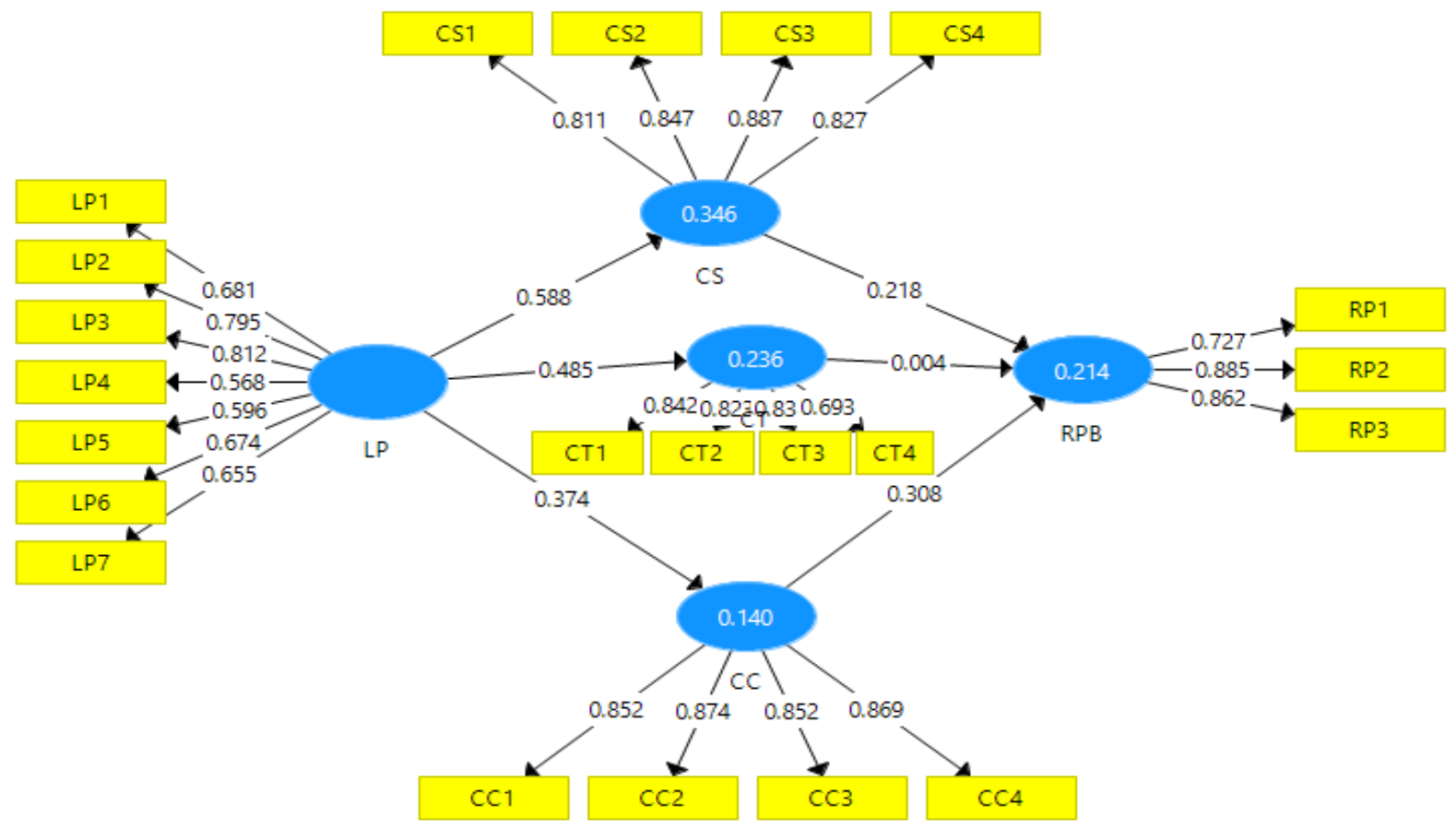

Figure 2: Path modeling and factor loading results 


\subsection{Hypothesis test}

\begin{tabular}{|c|c|c|c|}
\hline Path & Hypothesis & $\begin{array}{l}\text { Path coefficients } \\
(\beta)\end{array}$ & Rejected/supported \\
\hline $\begin{array}{lll}\text { Loyalty Program } & (\mathrm{LP}) & \rightarrow \text { Customer } \\
\text { Satisfaction (CS) } & & \end{array}$ & $\mathrm{H} 1$ & $0.588^{a}$ & Supported \\
\hline Loyalty Program (LP) $\rightarrow$ Customer Trust $(\mathrm{CT})$ & $\mathrm{H} 2$ & $0.485 a$ & Supported \\
\hline $\begin{array}{l}\text { Loyalty Program } \quad(\mathrm{LP}) \quad \rightarrow \text { Customer } \\
\text { Commitment }(\mathrm{CC})\end{array}$ & $\mathrm{H} 3$ & $0.374 a$ & Supported \\
\hline $\begin{array}{l}\text { Customer Satisfaction } \\
\text { Purchase Behaviour (RP) }\end{array}$ & $\mathrm{H} 4$ & $0.218^{\mathrm{a}}$ & Supported \\
\hline $\begin{array}{l}\text { Customer Trust (CT) } \rightarrow \text { Repeat Purchase } \\
\text { Behaviour (RP) }\end{array}$ & H5 & 0.004 & Supported \\
\hline $\begin{array}{l}\text { Customer Commitment } \quad \text { (CC) } \rightarrow \text { Repeat } \\
\text { Purchase Behaviour (RP) }\end{array}$ & H6 & $0.308^{a}$ & Supported \\
\hline
\end{tabular}

Table 3: Results of structural equation model analysis

Our results indicate that all six hypotheses are supported with significant at $\mathrm{p}<.10$. As seen in Table 3 , H1 is supported by the hypothesis and is significant at $\mathrm{p}<.10$, indicated by a path coefficient of 0.588 . This implies that loyalty programs influence customers' satisfaction directly and positively. $\mathrm{H} 2$ is supported by the hypothesis and is significant at $\mathrm{p}<.10$, indicated by a path coefficient of 0.485 . This implies that loyalty programs have a positive and direct influence on customer trust. H3 is supported by the hypothesis and is significant at $\mathrm{p}<.10$, indicated by a path coefficient of 0.374 . This suggests that loyalty programs have a positive and direct influence on customer commitment. H4 is supported by the hypothesis and is significant at $\mathrm{p}<.10$, indicated by a path coefficient of 0.218 . This suggests that loyalty programs have a positive and direct influence on repeat purchase behaviour. Furthermore, this relationship suggests that an increase in customer satisfaction also leads to an increase in repeat purchase behaviour. H5 is supported by the hypothesis and is significant at $\mathrm{p}<.10$, indicated by a path coefficient of 0.004. This suggests that customer trust has a positive and direct influence on repeat purchase behaviour. It should also be noted that, of all the six relationships, H5 is the weakest relationship. This suggests that, of all the three factors that influence repeat purchase behaviour, namely customer satisfaction, customer trust and customer commitment, customer trust has the least influence on repeat purchase behaviour. H6 is supported by the hypothesis and is significant at $\mathrm{p}<.10$, indicated by a path coefficient of 0.308 . This suggests that customer commitment has a positive and direct influence on repeat purchase behaviour.

\section{Discussions and conclusions}

As has been mentioned, current research has found a relationship between loyalty programs and customer satisfaction. This finding is consistent with a study by Zakaria et al. (2014), who found that a loyalty program significantly influences customer satisfaction. This finding is supported by Bridson et al. (2008), who found that customer satisfaction played a mediating role in loyalty programs in a retail context. Moreover, this finding is supported by a similar study conducted by Vesel and Zabkar (2009), who suggested that customer satisfaction, has a strong mediating influence on loyalty programs. The results indicated that customer trust has a mediating influence on loyalty programs. This finding supports a study by Pizam (2015) which suggests that a lack of trust has a significant impact on the success of a loyalty program. This relationship also indicates that an improvement in the loyalty program can lead to an increase in customer trust. Omar et al. (2010), who found that trust is important in the retail loyalty program setting, support this finding. In addition, Lee et al. (2015) found that loyalty program financial rewards reinforce customer trust. According to this argument, the authors of the current study argue that loyalty programs have a measurable and notable influence on customer trust, and that this is consistent with the findings from this hypothesis. However, we would argue that researchers need to further examine the relationship between customer commitment and loyalty programs since this was found in the current study to have the weakest mediating effect. Noble et al. (2013), who maintain that loyalty programs increase customer commitment, support this finding. In addition, the finding of the current 
study is consistent with a study done by Ou et al. (2011), who posit that customer commitment has a measurable impact on a customer loyalty program. A study by Jai and King (2015) acknowledges a relationship between customer commitment and loyalty programs. In addition, this relationship suggests that the extent to which the loyalty program is effective is reflected by the level of commitment of customers to the company.

The mediating role of customer satisfaction on repeat purchase behaviour is consistent with the finding of a study by Magi (2003), who found customer satisfaction to be a critical determinant for customers' increased level of shopping at a retailer. Furthermore, Yi and La (2004) found customer satisfaction to directly impact repeat purchase behaviour. Moreover, the findings from a study done by Bolton et al. (2000) supported the finding of Yi and La (2004) that past customer satisfaction impacts on repeat purchase behaviour. These findings are consistent with those of Mpinganjira (2014), that customer satisfaction has a significant influence on repeat purchase behaviour. The mediating role of customer trust is consistent with a study by Hsu et al. (2014) who found customer trust to be a key factor affecting repeat purchase behaviour. Agudo et al. (2012) support this view with their view that customer trust is an indispensable condition for repeat purchase behaviour. In addition, this relationship suggests that an increase in customer trust leads to an increase in repeat purchase behaviour. Likewise, Chiu et al. (2012), who found that customer trust has a significant influence on repeat purchase behaviour. Lastly, a study which supports customer commitment as acting as a mediator is that of Keh and Xie (2015) which acknowledges that customer commitment has a mediating influence on repeat purchase intention. Furthermore, this relationship suggests that the more customers are committed to a brand, the more likely they are to purchase the same brand or product repeatedly. Sanchez and Iniesta (2004) support this finding by arguing that committed customers are likely to have a long-term relationship with a retailer. This is understood to mean that a committed customer is highly likely to repeat purchase at a retailer. Knox and Walker (2001) supported this view that commitment is a necessary condition for repeat purchase behaviour. In addition, the findings of Knox and Walker (2012) are consistent with a prior study done by Erciş, Ünal, Candan and Yıldırım (2006), who found customer commitment to influence repeat purchase intention.

The results of the current study offer some implications for managers in companies that make use of loyalty programs. Based on the findings of the study, loyalty programs positively influence customer satisfaction. This in turn implies that managers should strive towards having the best and most thoroughly thought out and researched loyalty programs available on the market in order to increase both the satisfaction and repeat purchase patterns of their customers. Thus, managers need to thoroughly and sensitively understand the causes of dissatisfaction that may exist amongst their customers. However, one should not ignore the argument made by Chiou and Droge (2006) that marketers should not only focus on satisfaction to persuade customers. Often customers do not adjust their purchase behaviour once they join a loyalty program, and therefore there should be a strategy in place to retain loyal customers and create bonds between the customer and the retailer (Gomez et al., 2006). It can be observed from the current study that loyalty programs tend to influence customers to trust companies and brands, and this finding, along with other similar findings, would suggest the importance of managers implementing loyalty programs for their companies or brands. In addition, it is strongly suggested that managerial implication stems from the fact that it can be observed that an improvement in a loyalty program has a direct and positive impact on customer commitment. This would suggest that managers should constantly move towards improving their loyalty programs to make customers more committed to a company or brand. This would include the willingness to award customers more benefits and rewards which should be the focus of building satisfaction, trust and commitment. Additionally, in line with prior studies, this study suggests that the efficient registration and use of loyalty programs have the potential to drive repeat purchase behaviour. A further recommendation would be to create a strong link to strategic partnerships, where a loyalty program can be applied to other industries that partner with retailers. It is hoped that Managers of companies in South Africa and in other developing countries could find this study insightful, appropriate for, and of value to, their retail sectors.

Furthermore, the insights of this study can be successfully implemented in other sectors that want to effectively penetrate the youth market. It can be argued that there needs to be a strategy that looks at 
the heterogeneity of customers and does not treat them all as being a homogenous group when there are clear differences in shopping behaviour and loyalty program use. There should therefore be different benefits and rewards for different segments of the consumer population, and each could or should be designed to meet the needs of the targeted segment. Loyalty program members belong to different segments and should be given different offers (Söderlund and Colliander, 2015).

\section{Limitations and direction for future research}

The sample for this study was limited to the segment of South African youth registered at the University of Witwatersrand. The use of research participants from a university may be seen to pose a limitation to a valid and comprehensive study. The sample focused specifically on Johannesburg-based respondents within the province of Gauteng. Researchers should obviously look at other provinces in South Africa and other developing countries which present other demographic factors and influences on consumer behaviour, especially amongst the youth. Moreover, the accuracy of the information may pose as a limitation considering the range of retail loyalty programs that exist. This study utilised retail loyalty programs from the food, clothing, health and beauty sectors. Future studies should look at focusing on one category from the retail sector. Researchers could study other sectors, such as the financial services, telecommunication, technology, or hospitality. The theoretical framework of this study was limited to assessing the mediating influence of loyalty program and repeat purchase behaviour without considering contextual factors and influences. It is critical for researchers to study this behaviour within the emerging markets context, while at the same time exploring other mediators such as word of mouth, cultural influences, innovation or brand equity. Future studies could explore the influence of loyalty program design and perceived benefits. Furthermore, researchers could explore and assess customer satisfaction, customer trust, and customer commitment from a social and economic rewards perspective. FurthermoreIn addition, researchers should look at the influence of loyalty program satisfaction, loyalty program trust and loyalty program commitment on repeat purchase behaviour.

Finally, in terms of the scope of the study, the current study was based on a convenience sampling method using a self-administered questionnaire. This research model and design does not offer any guarantee that research respondents will give honest responses to questions in the questionnaire. From a methodological perspective the study was cross sectional in research design. Future researchers could examine the behaviour of respondents over a longer period and use stratified or cluster sampling that is non-random, and the respondents could be monitored over a period to examine and triangulate their behaviour. From a sample perspective, the sample was limited to university students between the ages of 18 and 24 within the youth market. We would recommend researchers consider exploring the 25-35 age group to offer a more complete - and possibly comparative - picture of the impact of loyalty programs on the wider youth segment (ages 18-35), as well as on other customers over the age of 35. A qualitative and/or mixed quantitative/qualitative study could also offer a more in-depth perspective on the motivations and consumer experiences of these segments of the consumer population both in South Africa and in other developing countries.

\section{References}

Agudo, J., Crespo, A., \& del Bosque, I. (2012). Adherence to customer loyalty programmes and changes in buyer behaviour. The Service Industries Journal, 32(8), 1323-1341.

Aktepe, A., Ersöz, S., \& Toklu, B. (2014). Customer satisfaction and loyalty analysis with classification algorithms and Structural Equation Modeling. Computers and Industrial Engineering, 86(1), 95-106.

Amine, A. (1998). Customers' true brand loyalty: the central role of commitment. Journal of Strategic Marketing, 6(4), 305-319.

Aydin, N., Celik, E., \& Gumus, A. T. (2015). A hierarchical customer satisfaction framework for evaluating rail transit systems of Istanbul. Transportation Research Part A: Policy and Practice, 77(1), 61-81.

Atsmon, Y., Kuentz, J., \& Seong, J. (2012). Building brands in emerging markets. McKinsey Quarterly, 9, 1-6.

Baloglu, S., Zhong, Y. Y., \& Tanford, S. (2017). Casino loyalty: The influence of loyalty program, switching costs, and trust. Journal of Hospitality and Tourism Research, 41(7), 846-868.

Barakat, L. L., Ramsey, J. R., Lorenz, M. P., \& Gosling, M. (2015). Severe service failure recovery revisited: Evidence of its determinants in an emerging market context. International Journal of Research in Marketing, 32(1), 113-116.

Barkaoui, M., Berger, J., \& Boukhtouta, A. (2015). Customer satisfaction in dynamic vehicle routing problem with time windows. Applied Soft Computing, 35(1), 423-432.

www.jbrmr.com A Journal of the Academy of Business and Retail Management (ABRM) 
Beneke, J., Blampied, S., Cumming, R., \& Parkfelt, J. (2015). Scrutinising the effectiveness of customer loyalty programmes: A study of two large supermarket chains in South Africa. African Journal of Business Management, 9(5), 212-222.

Bolton, R. N., Kannan, P. K., \& Bramlett, M. D. (2000). Implications of loyalty program membership and service experiences for customer retention and value. Journal of the academy of marketing science, 28(1), 95-108.

Bowen, J. T., \& Shoemaker, S. (1998). Loyalty: A strategic commitment. Cornell Hotel and Restaurant Administration Quarterly, 39(1), 12-25.

Brashear-Alejandro, T., Kang, J., \& Groza, M. D. (2016). Leveraging loyalty programs to build customer-company identification. Journal of Business Research, 69(3), 1190-1198.

Bridson, K., Evans, J., \& Hickman, M. (2008). Assessing the relationship between loyalty program attributes, store satisfaction and store loyalty. Journal of Retailing and Customer Services, 15(5), 364-374.

Bügel, M. S., Verhoef, P. C., \& Buunk, A. P. (2011). Customer intimacy and commitment to relationships with firms in five different sectors: Preliminary evidence. Journal of Retailing and Consumer Services, 18(4), 247-258.

Caceres, R., \& Paparoidamis, N. G. (2007). Service quality, relationship satisfaction, trust, commitment and businessto-business loyalty. European Journal of Marketing, 41(7/8), 836-867.

Chang, P. C., \& Chen, S. J. (2011). Crossing the level of employee's performance: HPWS, affective commitment, human capital, and employee job performance in professional service organizations. The International Journal of Human Resource Management, 22(04), 883-901.

Chen, S. C., \& Quester, P. G. (2015). The relative contribution of love and trust towards customer loyalty. Australasian Marketing Journal (AMJ), 23(1), 13-18.

Chinomona, R., Mahlangu, D., \& Pooe, D. (2013). Brand service quality, satisfaction, trust and preference as predictors of consumer brand loyalty in the retailing industry. Mediterranean Journal of Social Sciences, 4(14), 181.

Chiou, J. S., \& Droge, C. (2006). Service quality, trust, specific asset investment, and expertise: Direct and indirect effects in a satisfaction-loyalty framework. Journal of the Academy of Marketing Science, 34(4), 613-627.

Chiu, C. M., Hsu, M. H., Lai, H., \& Chang, C. M. (2012). Re-examining the influence of trust on online repeat purchase intention: The moderating role of habit and its antecedents. Decision Support Systems, 53(4), 835-845.

Demoulin, N. T., \& Zidda, P. (2008). On the impact of loyalty cards on store loyalty: Does the customers' satisfaction with the reward scheme matter. Journal of Retailing and Consumer Services, 5(5), 386-398.

Dorotic, M., Bijmolt, T. H., \& Verhoef, P. C. (2012). Loyalty Programmes: Current Knowledge and Research Directions. International Journal of Management Reviews, 14(3), 217-237.

Dowling, G. R., \& Uncles, M. (1997). Do customer loyalty programs really work? Sloane Management Review, Summer, 71-82.

Dunn, T. J., Baguley, T., \& Brunsden, V. (2013), “From alpha to omega: A practical solution to the pervasive problem of internal consistency estimation. British Journal of Psychology, 105(3), 399-412.

Dwivedi, A., \& Johnson, L. W. (2013). Trust-commitment as a mediator of the celebrity endorser-brand equity relationship in a service context. Australasian Marketing Journal (AMJ), 21(1), 36-42.

Eason, C. C., Bing, M. N., \& Smothers, J. (2015). Reward me, charity, or both? The impact of fees and benefits in loyalty programs. Journal of Retailing and Consumer Services, 25, 71-80.

Erciş, A., Ünal, S., Candan, F. B., \& Yildırım, H. (2012). The effect of brand satisfaction, trust and brand commitment on loyalty and repurchase intentions. Procedia-Social and Behavioral Sciences, 58, 1395-1404.

Evanschitzky, H., Iyer, G. R., Plassmann, H., Niessing, J., \& Meffert, H. (2006). The relative strength of affective commitment in securing loyalty in service relationships," Journal of Business Research, 59(12), 1207-1213.

Fraering, M., and M. S. Minor, (2006). Sense of Community: An Exploratory Study of US Consumers of Financial Services. International Journal of Bank Marketing, 24(5), 284-306.

Fullerton, G. (2004). When does commitment lead to loyalty? Journal of Service Research, 5(4), 333-344.

Garbarino, E., \& Johnson, M. S. (1999). The different roles of satisfaction, trust, and commitment in customer relationships. The Journal of Marketing, 63(2), 70-87.

Garnefeld, I., Eggert, A., Helm, S. V., \& Tax, S. S. (2013). Growing Existing Customers' Revenue Streams Through Customer Referral Programs. Journal of Marketing, 77(4), 17-32.

Goel, A., Kamble, V., Banerjee, S., \& Goel, A. (2017). Network Formation of Coalition Loyalty Programs. ACM SIGMETRICS Performance Evaluation Review, 44(3), 15-20.

Gómez, B., Arranz, A., \& Cillán, J. (2006). The role of loyalty programs in behavioral and affective loyalty. Journal of Consumer Marketing, 23(7), 387-396.

Heerde, H. J. V., \& Bijmolt, T. H. (2005). Decomposing the promotional revenue bump for loyalty program members versus non-members. Journal of Marketing Research, 42(4), 443-457.

Henderson, C. M., Beck, J. T., \& Palmatier, R. W. (2011). Review of the theoretical underpinnings of loyalty programs. Journal of Consumer Psychology, 21(3), 256-276. 
Hsu, M. H., Chang, C. M., \& Chuang, L. W. (2015). Understanding the determinants of online repeat purchase intention and moderating role of habit: The case of online group-buying in Taiwan. International Journal of Information Management, 35(1), 45-56.

Jai, T. M. C., \& King, N. J. (2015). Privacy versus reward: Do loyalty programs increase consumers' willingness to share personal information with third-party advertisers and data brokers? Journal of Retailing and Consumer Services, 28, 296-303.

Kao, D. T. (2015). The moderating roles of ad claim type and rhetorical style in the ads of competitor brands for diluting the consumers' brand commitment to the existing brands. Asia Pacific Management Review, 21(1), 9-17.

Kang, J., Alejandro, T. B., \& Groza, M. D. (2015). Customer-company identification and the effectiveness of loyalty programs. Journal of Business Research, 68(2), 464-471

Keh, H. T., \& Xie, Y. (2009). Corporate reputation and customer behavioral intentions: The roles of trust, identification and commitment. Industrial Marketing Management, 38(7), 732-742.

Keropyan, A., \& Gil-Lafuente, A. M. (2012). Customer loyalty programs to sustain consumer fidelity in mobile telecommunication market. Expert Systems with Applications, 39(12), 11269-11275.

Knox, S., \& Walker, D. (2001). Measuring and managing brand loyalty. Journal of Strategic Marketing, 9(2), 111-128.

Lee, J. S., Tsang, N., \& Pan, S. (2015). Examining the differential effects of social and economic rewards in a hotel loyalty program. International Journal of Hospitality Management, 49, 17-27.

Leenheer, J., Van Heerde, H. J., Bijmolt, T. H., \& Smidts, A. (2007), “Do loyalty programs really enhance behavioral loyalty? An empirical analysis accounting for self-selecting members," International Journal of Research in Marketing, 24(1), 31-47.

Leong, L. Y., Hew, T. S., Lee, V. H., \& Ooi, K. B. (2015). An SEM-artificial-neural-network analysis of the relationships between customer satisfaction and loyalty among low-cost and full-service airline. Expert Systems with Applications, 42, 2260-6643.

Leva, M., \& Ziliani, C. (2017). Towards digital loyalty programs: insights from customer medium preference segmentation. International Journal of Retail E Distribution Management, 45(2), 195-210.

Lima, S., \& Lee, B. (2015). Loyalty Programs and Dynamic Consumer Preference in Online Markets. Decision Support Systems, 78, 104-112

Liu, Y. (2007). The long-term impact of loyalty programs on consumer purchase behavior and loyalty. Journal of Marketing, 71(4), 19-35.

Liu-Thompkins, Y., \& Tam, L. (2013). Not all repeat customers are the same: Designing effective cross-selling promotion based on attitudinal loyalty and habit. Journal of Marketing, 77(5), 21-36.

Mägi, A. W. (2003). Share of wallet in retailing: the effects of customer satisfaction, loyalty cards and shopper characteristics. Journal of Retailing, 79(2), 97-106.

Martin, J., Mortimer, G., \& Andrews, L. (2015). Re-examining online customer experience to include purchase frequency and perceived risk. Journal of Retailing and Consumer Services, 25, 81-95.

Martínez, P., \& del Bosque, I. R. (2013). CSR and customer loyalty: The roles of trust, customer identification with the company and satisfaction. International Journal of Hospitality Management, 35, 89-99.

Mathe-Soulek, K., Slevitch, L., \& Dallinger, I. (2015). Applying mixed methods to identify what drives quick service restaurant's customer satisfaction at the unit-level. International Journal of Hospitality Management, 50, 46-54.

Mattila, A. S. (2006). How affective commitment boosts guest loyalty (and promotes frequent-guest programs). Cornell Hotel and Restaurant Administration Quarterly, 47(2), 174-181.

Meyer-Waarden, L. (2015). Effects of loyalty program rewards on store loyalty. Journal of Retailing and Consumer Services, 24, 22-32.

Meyer-Waarden, L., \& Benavent, C. (2009). Grocery retail loyalty program effects: self-selection or purchase behaviour change? Journal of the Academy of Marketing Science, 37(3), 345-358.

Minarti, S. N., \& Segoro, W. (2014). The Influence of Customer Satisfaction, Switching Cost and Trusts in a Brand on Customer Loyalty-The Survey on Student as im3 Users in Depok Indonesia. Procedia-Social and Behavioral Sciences, 143, 1015-1019.

Morgan, R. M., \& Hunt, S. D. (1994). The commitment-trust theory of relationship marketing. The Journal of Marketing, 58(3), 20-38.

Mouwen, A. (2015). Drivers of customer satisfaction with public transport services. Transportation Research Part A. Policy and Practice, 78, 1-20.

Mpinganjira, M. (2014). Understanding online repeat purchase intentions: A relationship marketing perspective. Management Journal of Contemporary Management Issues, 19(2), 117-135.

Noble, S. M., Esmark, C. L., \& Noble, C. H. (2014). Accumulation versus instant loyalty programs: The influence of controlling policies on customers' commitments. Journal of Business Research, 67(3), 361-368.

Omar, N. A., \& Musa, R. (2009). Benefits-satisfaction-loyalty linkages in retail loyalty card program model: exploring the roles of program trust and program commitment. Advances in Customer Research, 8(1), 258-262. 
Omar, N. A., Wel, B. C., Aniza, C., Musa, R., \& Nazri, M. A. (2010). Program benefits, satisfaction and loyalty in retail loyalty program: Exploring the roles of program trust and program commitment. The IUP Journal of Marketing Management, 9(4), 6-28.

Pandit, A., \& Vilches-Montero, S. (2016). Are reward cards just a business deal? The role of calculative versus emotional card commitment in driving store loyalty. Journal of Retailing and Consumer Services, 31, 355-360.

Paul, M., Hennig-Thurau, T., Gremler, D. D., Gwinner, K. P., \& Wiertz, C. (2009). Toward a theory of repeat purchase drivers for consumer services. Journal of the Academy of Marketing Science, 37(2), 215-237.

Pizam., A. (2015). Hotel Loyalty Programs: The Halo Effect. International Journal of Hospitality Management, 48, 167-168.

Radojevic, T., Stanisic, N., \& Stanic, N. (2015). Ensuring positive feedback: Factors that influence customer satisfaction in the contemporary hospitality industry. Tourism Management, 51, 13-21.

Rasheed, F. A., \& Abadi, M. F. (2014). Impact of Service Quality, Trust and Perceived Value on Customer Loyalty in Malaysia Services Industries. Procedia-Social and Behavioral Sciences, 164, 298-304.

Roberts-Lombard, M. (2009). Customer Retention Strategies of Fast-Food Outlets in South Africa: A Focus on Kentucky Fried Chicken (KFC), Nando's, and Steers. Journal of African Business, 10(2), 235-249.

Söderlund, M., \& Colliander, J. (2015). Loyalty program rewards and their impact on perceived justice, customer satisfaction, and repatronize intentions. Journal of Retailing and Consumer Services, 25, 47-57.

Statistics South Africa. (2014). The labour markets dynamics in South Africa report 2014. Statistics South Africa.

Stathopoulou, A., \& Balabanis, G. (2016). The effects of loyalty programs on customer satisfaction, trust, and loyalty toward high-and low-end fashion retailers. Journal of Business Research, 69(12), 5801-5808.

Terblanche, N. S., \& Boshoff, C. (2010). Quality, value, satisfaction and loyalty amongst race groups: a study of customers in the South African fast food industry. South African Journal of Business Management, 41(1), 1-9.

Veloutsou, C. (2015). Brand evaluation, satisfaction and trust as predictors of brand loyalty: the mediator-moderator effect of brand relationships. Journal of Consumer Marketing, 32(6), 405-421.

Vesel, P., \& Zabkar, V. (2009). Managing customer loyalty through the mediating role of satisfaction in the DIY retail loyalty program. Journal of Retailing and Consumer Services, 16(5), 396-406.

Xie, L. S., Peng, J. M., \& Huan, T. C. (2014). Crafting and testing a central precept in service-dominant logic: Hotel employees' brand-citizenship behaviour and customers' brand trust. International Journal of Hospitality Management, 42, 1-8.

Yang, Z., Wang, X., \& Su, C. (2006). A review of research methodologies in international business. International Business Review, 15, 601-617.

Yan, W., \& Cui, Z. (2016). Factors contributing to popularity of loyalty programs: evidence from emerging markets. Cornell Hospitality Quarterly, 57(2), 184-192.

Yi, Y., \& Jeon, H. (2003). Effects of loyalty programs on value perception, program loyalty, and brand loyalty. Journal of the Academy of Marketing Science, 31(3), 229-240.

Yi, Y., \& La, S. (2004). What influences the relationship between customer satisfaction and repurchase intention? Investigating the effects of adjusted expectations and customer loyalty. Psychology and Marketing, 21(5), 351373.

Zakaria, I., Rahman, B. A., Othman, A. K., Yunus, N. A. M., Dzulkipli, M. R., \& Osman, M. A. F. (2014). The Relationship between Loyalty Program, Customer Satisfaction and Customer Loyalty in Retail Industry: A Case Study. Procedia-Social and Behavioural Sciences, 129, 23-30. 